\title{
Uji Toksisitas Beberapa Fungisida Nabati terhadap Penyakit Layu Fusarium (Fusarium oxysporum) pada Tanaman Kentang (Solanum tuberosum L.) secara In Vitro \\ (Toxicity Test of several Biofungicides in controlling Fusarium wilt (Fusarium oxysporum) in Potato Plants (Solanum tuberosum L.) by In Vitro)
}

\author{
Ghea Dotulong ${ }^{\left.1^{*}\right)}$, Stella Umboh ${ }^{1)}$, Johanis Pelealu ${ }^{1)}$, \\ 1) Program Studi Biologi, FMIPA Universitas Sam Ratulangi, Manado 95115 \\ *Email korespondensi: dotulong.ghea@gmail.com
}

Diterima 9 Juli 2019, diterima untuk dipublikasi 10 Agustus 2019

\begin{abstract}
Abstrak
Tanaman kentang (Solanum tuberosum L.) adalah salah satu tanaman hortikultura yang sering mengalami penurunan dari segi produksi dan produktivitasnya, akibat adanya serangan penyakit layu yang salah satunya disebabkan oleh Fusarium oxysporum. Tujuan penelitian ini adalah mengidentifikasi toksisitas beberapa fungisida nabati dalam mengendalikan penyakit Layu Fusarium (F. oxysporum) pada tanaman kentang (Solanum tuberosum L.) secara In Vitro. Metode Penelitian yang digunakan yaitu metode umpan beracun. Data dianalisis dengan Rancangan Acak Lengkap (RAL) dengan Analisis Varian (ANAVA) yang dilanjutkan dengan menggunakan metode BNT (Beda Nyata Terkecil). Hasil Penelitian, diperoleh nilai toksisitas fungisida nabati tertinggi yaitu pada ekstrak daun sirsak dengan nilai $H R(69,44 \%)$, kategori berpengaruh, ditandai dengan diameter koloni 2,75 cm (100ppm) dan yang terendah toksisitasnya yaitu pada ekstrak daun jeruk purut dengan nilai $H R$ (49,81\%), kategori cukup berpengaruh ditandai dengan diameter koloni 3,75 cm (25ppm). Semakin tinggi konsentrasi yang diujikan maka semakin tinggi toksisitas dari fungisida nabati yang diberikan.

Kata Kunci: fungisida nabati, Fusarium oxysporum, tanaman kentang, In Vitro
\end{abstract}

\begin{abstract}
Potato plants (Solanum tuberosum L.) is one of the horticulture plants which often decreases in terms of production and productivity, due to the attack of wilt, one of which is caused by Fusarium oxysporum. The purpose of this study was to determine the toxicity of several biofungicides in controlling Fusarium wilt ( $F$. oxysporum) in potato plants (Solanum tuberosum L.) in Vitro. The research method used was the In Vitro method with the poison bait method. Data were analyzed by Completely Randomized Design with Variant Analysis (ANAVA), followed by the BNT method. The results showed that the highest biofungicide toxicity value was soursop leaf extract with $H R$ values (69.44\%), influential categories, characterized by colony diameter $2.75 \mathrm{~cm}$ (100ppm) and the lowest toxicity, namely in kaffir lime leaf extract with a value of $H R(49.81 \%)$, quite influential category was characterized by colony diameter of $3.75 \mathrm{~cm}$ (25ppm). The higher the concentration tested, the higher the toxicity of the biofungicide given.
\end{abstract}

Keywords: biofungicides, Fusarium oxysporum, Potato Plants, In Vitro. 


\section{PENDAHULUAN}

Tanaman Kentang (Solanum tuberosum L.) adalah salah satu tanaman hortikultura berupa umbiumbian dari famili Solanaceae, yang menjadi andalan sektor pertanian di Indonesia dan semakin meningkat permintaannya akhir-akhir ini (Purwantisari et al. 2008). Kentang mempunyai nilai gizi yang cukup tinggi dan banyak permintaan di pasaran Indonesia yang menyebabkan kentang mulai banyak diproduksi pada daerah yang kurang produktif (Suryanti et al. 2013).

Kebutuhan konsumsi kentang diperkirakan akan meningkat beberapa tahun ke depan. Hal ini akan mengakibatkan meluasnya pendayagunaan produksi kentang di Indonesia sebagai prospek pengembangan agribisnis bagi pelaku usaha tani. Peningkatan Permintaan kentang tidak diimbangi dengan produksinya (Tirtana et al. 2013). Rata-rata produksi kentang di Indonesia masih tergolong sangat rendah dibandingkan dengan produksi kentang di Eropa dan Amerika Serikat. Menurut BPS (2017).

Menurut Suhardi (1993) dalam Suryanti (2013), beberapa kendala yang dihadapi petani dalam budidaya tanaman kentang diantaranya jarang terdapat bibit yang tahan terhadap serangan penyakit. Hal ini disebabkan oleh beberapa faktor yaitu cuaca yang kurang mendukung, mutu benih yang rendah, teknik budidaya yang tidak sesuai, serta organisme pengganggu tanaman (OPT). Pada umumnya, lahan tanaman kentang sudah terkontaminasi patogen. $\mathrm{Hal}$ ini ditunjukkan dengan selalu dijumpainya penyakit pada setiap musim tanam, sehingga lahan tersebut umumnya bersifat tular tanah, yang mampu hidup, menyebar, dan bertahan dalam jangka waktu lama di dalam tanah (Semangun, 2006). Penyakit busuk daun tanaman kentang atau yang disebut Penyakit Lodoh merupakan penyakit yang paling serius di antara penyakit dan hama yang menyerang tanaman kentang di Indonesia (Purwantisari et al. 2008).

Penyakit yang paling banyak menyerang tanaman kentang yaitu penyakit layu yang disebabkan oleh jamur patogen. Jamur patogen penyebab penyakit yang pernah dilaporkan menyerang tanaman kentang di sebagian besar daerah Tunisia adalah Phytopthora infestan dan Fusarium sp. (Suryanti et al. 2013). Fusarium oxysporum dapat bertahan dalam tanah lebih dari 10 tahun dalam bentuk klamidospora (Semangun, 2001). Jamur ini dapat menyebabkan kerugian besar terutama pada varietas yang rentan dan pada kondisi lingkungan yang sesuai (Agrios 2005).

Petani mengandalkan fungisida berbahan kimia untuk menanggulangi penyakit layu Fusarium pada tanaman kentang. Menurut Prajnanta (1995), pengendalian secara kimiawi dapat menimbulkan masalah baru yaitu pencemaran lingkungan dan ketahanan hama tanaman (resistensi). Penelitian-penelitian yang telah dilakukan sebelumnya, bahan kimia mempunyai efek negatif pada manusia dan hewan, seperti berbagai macam penyakit berbahaya seperti kanker dan cacat tubuh (Shim et al. 2009), kemandulan (Sutikno 1992), dan kematian (Suryanti 2013) serta resistensi patogen, pencemaran lingkungan, dan matinya organisme non target (Oka 1995). Oleh karena itu, perlu dicari cara pengendalian lain yang efektif tetapi ramah lingkungan (Wachjadi et al. 2013). 
Pengendalian penyakit dengan fungisida dan bakterisida sintetis oleh para petani kentang selama ini tidak efektif dalam mengendalikan penyakit yang disebabkan oleh jamur patogen. Berbagai masalah yang ditimbulkan oleh jamur patogen merugikan bagi kehidupan manusia secara langsung maupun tidak langsung. Secara langsung dapat berupa residu yang melekat pada hasil tanaman dan secara tidak langsung akan mengganggu kesehatan konsumen, pencemaran lingkungan, serta membunuh organisme lainnya yang bukan sasaran (Purwantisari et al. 2008).

Alternatif pengendalian penyakit layu Fusarium yang ramah lingkungan adalah dengan menggunakan fungisida alami dari mikroba antagonis dan ekstrak tumbuhan. Fungisida nabati mengandung senyawa bioaktif yang efektif menghambat atau mengendalikan patogen terbawa benih baik secara in vitro maupun in vivo (Halimursyadah et al. 2017). Beberapa jenis fungisida alami adalah ekstrak daun sirih, daun pepaya, daun sirsak, dan daun jeruk purut dapat mengendalikan penyakit patogen pada tanaman hortikultura. Penelitian yang dilakukan oleh Phabiola (2003) dan Apriani (2014), menemukan bahwa penyakit layu Fusarium pada tanaman tomat dapat dikendalikan dengan ekstrak daun Sirih. Penelitian ini bertujuan untuk mengidentifikasi toksisitas beberapa fungisida nabati dalam mengendalikan penyakit Layu Fusarium ( $F$. oxysporum) pada tanaman kentang (Solanum tuberosum L.) secara In Vitro. Metode Penelitian yang digunakan yaitu metode umpan beracun.

\section{METODE}

Preparasi fungisida nabati (daun pepaya, daun sirsak, daun jeruk purut)

Daun pepaya, daun sirsak, dan daun jeruk purut yang sehat dan segar diambil di daerah Kampus masing-masing sebanyak 500 - 1000 gram. Daun yang telah diambil tersebut lalu dibersihkan dan dicuci menggunakan aquades, selanjutnya bahan-bahan tersebut dikering anginkan selama 36 jam (Susilo 2016). Serbuk kering dari masingmasing daun dimaserasi dengan etanol $96 \%$ perbandingan 1:5 (w/v).

Campuran ini kemudian dikocok, kemudian diendapkan selama lima hari, disaring sehingga memperoleh filtrat ke-1 dan ampas. Kemudian ampas dilarutkan kembali dengan pelarut etanol 96\%. Kemudian didiamkan selama 3 hari dan disaring untuk memperoleh filtrate ke-2 dan ampas, lalu filtrat digabung (1 dan 2), dan dipekatkan dengan rotary evaporator atau water bath pada suhu $40-50^{\circ} \mathrm{C}$ hingga diperoleh ekstrak kasar (krud). Krud ini siap digunakan dengan mencampurkannya dalam media PDA (Linda 2011).

\section{Pembuatan Konsentrasi Uji dan Kontrol}

Ekstrak etanol Fungisida Nabati dibuat empat seri konsentrasi yaitu 25 ppm, 50 ppm, 75 ppm, dan 100 ppm serta control (0 ppm) dengan rumus: $V_{1} \times M_{1}=V_{1} \times M_{2}$

Ket: $V_{1}=$ Volume sebelum pengenceran, $\mathrm{M}_{1}=$ onsentrasi sebelum pengenceran, $\mathrm{V}_{2}=$ Volume setelah pengenceran, dan $\mathrm{M}_{2}=$ Konsentrasi setelah pengenceran. 


\section{Tahap Pengujian Fungisida Nabati Secara In Vitro}

\section{Uji Toksisitas dengan metode umpan beracun}

Untuk melakukan uji toksisitas masing-masing fungisida nabati mengikuti metode yang digunakan oleh Humaidi et al. (1999) yaitu pengujian secara invitro dengan metode umpan beracun, yang dilakukan dengan menumbuhkan inokulum jamur F.oxysporum pada media PDA yang sudah bercampur dengan fungisida. Metode ini dilakukan dengan mencampur larutan fungisida dengan konsentrasi yang berbeda (0 ppm, 25 ppm, 50 ppm, 75 ppm, dan 100 ppm) sebelum media PDA di dalam cawan petri memadat. Setelah medium PDA memadat, inokulum jamur yang diperoleh ditumbuhkan dengan meletakkan di tengah-tengah media PDA. Perlakuan ini dibandingkan dengan perlakuan kontrol yang tidak diberikan perlakuan menggunakan fungisida. Pengamatan dilakukan dengan mengukur diameter koloni jamur yang tumbuh hingga koloni jamur pada kontrol penuh selama tujuh hari.

Menurut Linda (2011), untuk menghitung diameter koloni jamur yang tumbuh dengan membuat garis vertikal dan horisontal yang titik potong kedua garis tepat berada di tengah koloni jamur (Gambar 1). Cara pengukuran diameter koloni jamur F.oxysporum pada cawan petri berdasarkan rumus:

Dimana:

$$
\mathrm{D}=\frac{\mathrm{d} 1+\mathrm{d} 2}{2}
$$

$$
\begin{array}{ll}
\mathrm{D} & =\text { diameter koloni jamur } \\
\mathrm{d} 1 & =\text { diameter vertical jamur } \\
\mathrm{d} 2 & =\text { diameter horizontal jamur }
\end{array}
$$

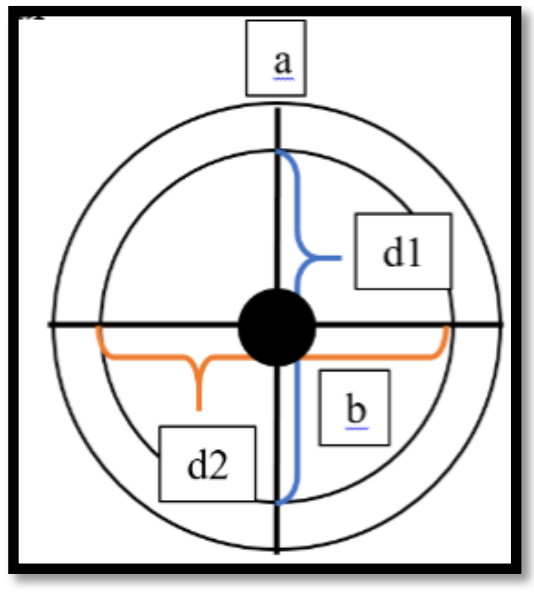

Gambar 1. Cara Pengukuran Diameter Koloni Jamur (a. cawan petri; b. koloni jamur;d1. diameter vertical jamur; d2. diameter horizontal) (Linda, 2011).

Penghitungan daya hambat relatif fungisida nabati terhadap pertumbuhan jamur dihitung sampai jamur tumbuh. Persentasi hambatan dihitung menurut rumus Pande et al. (1982) dalam Noveriza dan Tombe (2003) sebagai berikut:

Dimana :

$$
\mathrm{HR}=\frac{\mathrm{dk}-\mathrm{dp}}{\mathrm{dk}} \times 100 \%
$$

$\mathrm{HR}$ = hambatan relatif

$\mathrm{dk}=$ diameter kontrol

$\mathrm{dp}=$ diameter perlakuan

Pengaruh suatu fungisida dinilai dari kategori yang dikemukakan oleh Irasakti dan Sukatsa (1987) yaitu:

$$
\begin{aligned}
& 0=\text { tidak berpengaruh } \\
& >0-20 \%=\text { sangat kurang } \\
& >20-40 \%=\text { berpengaruh } \\
& >40-60 \%=\text { kurang berpengaruh } \\
& >60-80 \%=\text { cukup berpengaruh } \\
& >80 \%=\text { berpengaruh } \\
& 0-40 \%=\text { sangat berpengaruh } \\
& >40-80 \%=\text { kurang efektif } \\
& \text { efektif }
\end{aligned}
$$




\section{Analisis data}

Rancangan yang digunakan pada pengujian toksisitas fungisida secara in vitro yaitu Rancangan Acak Lengkap ( $R A L$ ) yang masing-masing diulang tiga kali. Hasil yang diperoleh dianalisis menggunakan Analisis Varian (ANAVA) Satu Arah dengan uji lanjut menggunakan metode BNT (Beda Nyata Terkecil) (Hujjatusnaini 2012).
HASIL DAN PEMBAHASAN

Hasil Uji Toksisitas Ekstrak Fungisida Nabati

Pengujian toksisitas fungisida nabati terhadap jamur F.oxysporum dilakukan dengan metode umpan beracun. Berdasarkan pengujian toksisitas fungisida nabati pada 5 perlakuan $(A=$ kontrol $-E=100 \mathrm{ppm})$ diperoleh diameter koloni jamur $F$. oxysporum yang berkisar antara 2,25 $\mathrm{cm}-8,5 \mathrm{~cm}$ (Tabel 1).

Tabel 1. Diameter Koloni Jamur F. oxysporum dan Hambatan Relatif Beberapa Fungisida Nabati

\begin{tabular}{|c|c|c|c|c|c|}
\hline \multirow[b]{2}{*}{ Ekstrak } & \multirow[b]{2}{*}{$\begin{array}{l}\text { Konsentrasi } \\
\text { Perlakuan }\end{array}$} & \multicolumn{2}{|c|}{ Diameter $(\mathrm{cm})$} & \multirow[b]{2}{*}{$\begin{array}{l}\mathrm{HR} \\
(\%)\end{array}$} & \multirow[b]{2}{*}{ Kategori } \\
\hline & & DP & DK & & \\
\hline \multirow{5}{*}{ SIRSAK } & A & 9.00 & 9 & 0.00 & Tidak berpengaruh \\
\hline & $\mathrm{B}$ & 3.98 & 9 & 55.74 & Cukup berpengaruh \\
\hline & C & 2.95 & 9 & 67.22 & Berpengaruh \\
\hline & D & 2.88 & 9 & 67.96 & Berpengaruh \\
\hline & $E$ & 2.75 & 9 & 69.44 & Berpengaruh \\
\hline \multirow{5}{*}{ PEPAYA } & $A$ & 9.00 & 9 & 0.00 & Tidak berpengaruh \\
\hline & $B$ & 4.08 & 9 & 54.63 & Cukup berpengaruh \\
\hline & C & 3.32 & 9 & 63.15 & Berpengaruh \\
\hline & D & 3.28 & 9 & 63.52 & Berpengaruh \\
\hline & $E$ & 3.17 & 9 & 64.81 & Berpengaruh \\
\hline \multirow{5}{*}{$\begin{array}{l}\text { JERUK } \\
\text { PURUT }\end{array}$} & $A$ & 9.00 & 9 & 0.00 & Tidak berpengaruh \\
\hline & $\mathrm{B}$ & 4.52 & 9 & 49.81 & Cukup berpengaruh \\
\hline & C & 4.05 & 9 & 55.00 & Cukup berpengaruh \\
\hline & D & 3.02 & 9 & 66.48 & Berpengaruh \\
\hline & $E$ & 2.82 & 9 & 68.70 & Berpengaruh \\
\hline
\end{tabular}

$\begin{array}{lll}\text { Keterangan : } & \mathrm{DP}=\text { Diameter Perlakuan } & \mathrm{A}=0 \mathrm{ppm} \\ \mathrm{DK}=\text { Diameter Kontrol } & \mathrm{B}=25 \mathrm{ppm} \\ \mathrm{HR}=\text { Hambatan Relatif } & \mathrm{C}=50 \mathrm{ppm} \\ & & \mathrm{D}=75 \mathrm{ppm} \\ & \mathrm{E}=100 \mathrm{ppm}\end{array}$

Dari data Tabel 1 di atas, pada ekstrak daun sirsak, diameter koloni terbesar terdapat pada perlakuan $100 \mathrm{ppm}(69,44 \%)$ dan terkecil terdapat pada perlakuan $25 \mathrm{ppm}$ $(55,74 \%)$, pada ekstrak daun pepaya, koloni terbesar terdapat pada perlakuan $100 \mathrm{ppm}(64,81 \%)$ dan yang terkecil pada perlakuan 25 ppm (54,63\%), sedangkan pada ekstrak daun jeruk purut, koloni terbesar terdapat pada perlakuan 
100 ppm (68,70\%) dan yang terkecil pada perlakuan $25 \mathrm{ppm}$ (49,81\%). Dari gambaran hasil ini dapat diketahui ternyata diameter koloni jamur terbesar terdapat pada ekstrak daun sirsak (100 ppm) dengan nilai HR $(69,44 \%)$ kategori berpengaruh (Gambar 2) dan terendah terdapat pada ekstrak daun jeruk purut (25 ppm) dengan nilai HR (49,81\%) kategori cukup berpengaruh (Gambar 2) Hasil ini menunjukkan bahwa ekstrak daun sirsak memiliki toksisitas yang tinggi, dimana aplikasinya berpengaruh terhadap pertumbuhan koloni jamur tersebut. Dengan demikian, dari ketiga ekstrak yang diujikan, maka ekstrak daun sirsak sangat berpotensi mempengaruhi pertumbuhan jamur $F$. oxysporum karena kandungan metabolit sekundernya mempunyai aktivitas yang kuat.

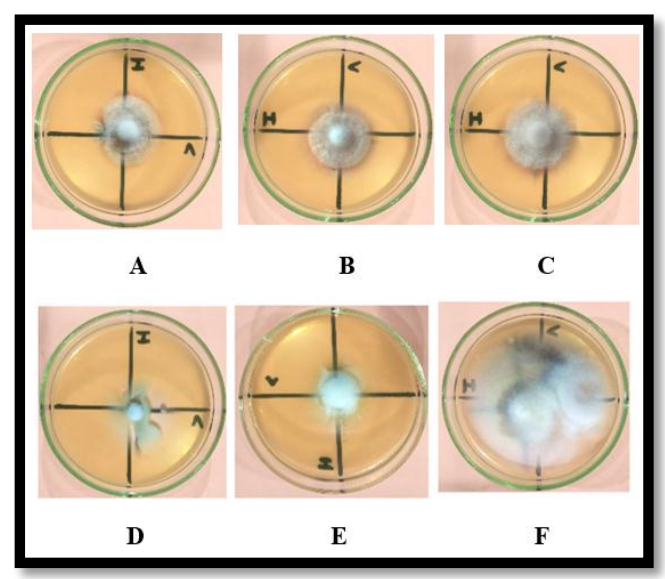

Gambar 2. Diameter zona hambat jamur F.oxysporum (A-C: pada fungisida nabati ekstrak daun sirsak konsentrasi 100 ppm ulangan 1-3; D-F: pada fungisida nabati ekstrak daun jeruk purut konsentrasi 25 ppm ulangan 1-3).

Hasil di atas memperlihatkan masing-masing fungisida nabati (ekstrak daun sirsak, daun papaya, dan daun jeruk purut) memiliki aktivitas senyawa antifungal terhadap $F$. oxysporum yang berbeda-beda dengan daya toksisitas yang berbeda pula. Perbedaan kandungan senyawa metabolit sekunder dapat terjadi dikarenakan perbedaan lingkungan tempat tumbuh tanaman, genetik, metode budidaya, waktu pengumpulan, serta pengolahan pasca panen. Hal ini juga dipengaruhi oleh beberapa faktor meliputi konsentrasi ekstrak, kadar senyawa metabolit sekunder terlarut, karakteristik, dan sifat jamur yang dihambat (Abdulah 2017). Senyawa metabolit sekunder dalam suatu tumbuhan dapat bervariasi karena kondisi lingkungannya, jenis varietas, kondisi fisiologis (tua atau muda) dan juga sifat kimianya (Apriyuslim 2015).

Dari Tabel 1 terlihat bahwa fungisida nabati ekstrak daun sirsak paling efektif persentase penghambatannya karena daya toksisitasnya yang tinggi tersebut dapat menghambat pertumbuhan koloni jamur $F$. oxysporum lebih tinggi dibandingkan dengan daun pepaya dan jeruk purut. $\mathrm{Hal}$ ini berarti fungisida nabati dari ekstrak daun sirsak yang paling kuat toksisitas hambatannya, hal ini sejalan dengan penelitian dari Angkay et al. (2006), dimana ekstrak daun sirsak dapat menghambat jamur Colletotrichum musae dan dapat menghambat jamur Candida albicans pada penelitian Rohadi (2015). Penghambatan ekstrak daun sirsak terhadap jamur $F$. oxysporum diduga terjadi oleh kemampuan penghambatan senyawa lektin, yaitu golongan senyawa proteinkarbohidrat yang tersebar luas di alam yang salah satunya terkandung pada daun sirsak (Gomez et al. 2012). Mekanismenya yaitu penghambatan germinasi spora 
untuk tumbuh menjadi miselium. Dinding sel fungi terganggu karena adanya sintesis kitin oleh lektin.

Selain kemampuan toksisitas daya hambat dari daun sirsak di atas, ternyata daun sirsak mengandung senyawa acetogenin, annocatanin, annocatalin, annohexocin, annonacin, annomuricin, anomurine, anonol, caclourine, gentisic acid, gigantetronin, asam linoleat, dan muricapentocin. Daun sirsak juga mengandung alkaloid polifenol, terpen (Leboeuf 1982), acetogenins (Wu et al. 1995), flavonoid (Kumar et al. 2012), dan lektin (Damico 2003).

Senyawa fenolik yang terdapat dalam daun sirsak dapat menghambat pertumbuhan jamur. Flavonoid dan Polifenol yang adalah senyawa fenolik bersifat antiseptis dan desinfektan bekerja dengan cara denaturasi dan koagulasi. Turunan senyawa fenol juga dapat merusak permeabilitas sel, membrane sel sehingga dapat mengakibatkan kebocoran sel, dan mikroba akan mengalami kematian (Siswono dan Soekardjo 2008).

Tanaman sirsak memiliki banyak kegunaan salah satunya sebagai antifungi. Zat Antifungal adalah suatu bahan yang dapat mengganggu pertumbuhan dan metabolisme fungi patogen. Pemakaian bahan antifungi merupakan usaha untuk mengendalikan fungi, yaitu segala kegiatan yang dapat menghambat, membasmi, atau menyingkirkan patogen tersebut (Pelczar dan Chan, 1988). Mekanisme antifungal dapat dikelompokkan sebagai gangguan pada membran sel.

Gangguan ini terjadi karena adanya ergasol dalam sel fungi, ini adalah komponen sterol yang sangat penting dan sangat mudah diserang oleh antibiotik turunan polien. Penghambatan biosintesis ergosterol dalam sel fungi, merupakan mekanisme yang disebabkan oleh senyawa turunan imidazol karena mampu menimbulkan ketidakaturan membran sitoplasma fungi dengan cara mengubah permeabilitas membran dan fungsi membran dalam proses pengangkutan senyawa-senyawa esensi yang dapat ketidakseimbangan metabolik sehingga menghambat pertumbuhan atau menimbulkan kematian sel fungi (Permana 2014).

Penggunaan fungisida nabati daun pepaya dengan konsentrasi 25 ppm, 50 ppm, 75 ppm, dan 100 ppm memberikan pengaruh terhadap pertumbuhan jamur walaupun tidak sebesar ekstrak daun sirsak. Hal ini terjadi karena adanya metabolit sekunder atau zat aktif berupa papain yang terdapat dalam daun pepaya tersebut, dimana papain merupakan enzim yang bersifat proteolitik yang mampu merombak protein dari patogen (Zusfahair et al. 2014). Hasil analisis fitokimia daun pepaya oleh Suresh et al. (2008) didapatkan bahwa daun papaya mengandung alkaloid, karpain, antraquinon, saponin, steroid, tannin, dan triterpenoid.

Penggunaan fungisida nabati daun jeruk purut dengan konsentrasi 25 ppm, 50 ppm, 75 ppm dan 100 ppm memberikan pengaruh terhadap pertumbuhan jamur $F$. oxysporum walaupun daya toksisitasnya yang paling kecil dari ketiga perlakuan yang diberikan. Daun jeruk purut sendiri memiliki lima komponen utama ekstrak ethyl acetate, yaitu limonene, citronellal, beta-pinene, sabinene, dan citronellyl acetate. 
Citronellal adalah salah satu komponen yang menunjukkan aktifitas antijamur yang paling kuat dibandingkan dengan geraniol, citral, dan geranyl asetat. Citronellal menghambat pertumbuhan secara total Aspergillus candidus, A.flavus, A.versicolor, Eurotium amstetodam, E. chevalieri, Penicillium adametzii, $P$. citrinum, $P$. griseovulum, dan $P$. islandicum (Nakahara 2003). Berdasarkan penelitian Noveriza (2010), ekstrak metanol daun jeruk purut dapat menghambat pertumbuhan $F$. oxysporum pada beberapa konsentrasi uji.

Hasil dari analisa ANAVA Satu Arah, ternyata memberikan pengaruh pada pemberian konsentrasi fungisida nabati terhadap jamur $F$. oxysporum, menunjukkan masing-masing nilai signifikan untuk daun sirsak, daun pepaya, dan daun jeruk purut, yaitu $0.000,0.000,0.009$ (sig<0,05). Hal ini menunjukkan bahwa terdapat perbedaan yang signifikan antara seri konsentrasi yang digunakan. Pengaruh masing-masing konsentrasi terhadap diameter zona hambat yang dihasilkan pada jamur F.oxysporun berbeda antara satu dengan yang lainnya. Adanya perbedaan yang signifikan tersebut, maka dianalisis lebih lanjut dengan menggunakan Uji BNT yang tujuannya untuk mengetahui pengaruh masing-masing konsentrasi terhadap diameter koloni jamur $F$. oxysporum.

Hasil analisis Uji BNT untuk hambatan relative menunjukkan lima macam perlakuan aplikasi fungisida nabati (0 ppm, 25 ppm, 50 ppm, 75 ppm dan 100 ppm) yang diujikan terhadap jamur $F$. oxysporum, ternyata fungisida nabati dari ekstrak daun sirsak yang sangat berpotensi mempengaruhi pertumbuhan jamur
F. oxysporum karena mempunyai aktivitas yang kuat. Hasil uji aktivitas toksisitas fungisida nabati untuk 7 hari inkubasi menunjukkan pengaruh yang sangat besar yang dapat menghambat perkembangan koloni jamur tanah tersebut, kenyataan ini didukung dengan hasil uji BNT taraf $5 \%$, dapat dilihat adanya perbedaan yang nyata pada hambatan relatif terhadap diameter koloni jamur $F$. oxysporum pada perlakuan konsentrasi fungisida nabati sebesar 0 ppm, 25 ppm, 50 ppm dan sangat berbeda nyata pada Hambatan Relatif (HR) pertumbuhan diameter koloni jamur dengan konsentrasi 75 ppm dan 100 ppm.

Kartasapoetra

menemukan bahwa ekstrak daun sirih memiliki daya hambat yang besar terhadap koloni jamur Fusarium yaitu sebesar $76,11 \%$, karena disebabkan oleh senyawa khas yang terdapat pada daun sirih yaitu fenol dan benomyl. Fenol merupakan salah satu senyawa yang dihasilkan tumbuhan yang dapat bersifat sebagai fungitoksik dan fungistatik (Salisbury dan Ross, 1998). Mekanisme aksi senyawa fenol sebagai fungisida dianggap berperan dalam antimetabolit dan menghambat fungsi enzim yang dihasilkan jamur (Stakman dan Harrar 1957 dalam Apriani 2014). Benomyl secara in vitro mampu menghambat pertumbuhan koloni jamur patogen dengan daya hambat sebesar $61,11 \%$.

Benomyl merupakan fungisida sistemik yang mempunyai spektrum yang luas untuk mengendalikan berbagai penyakit tanaman (Sudarmo 1991). Vyas (1984) dalam Apriani (2014) mengatakan tanaman tomat yang yang diinokulasikan $F$. oxysporum f.sp lycopersici dan perlakuan Benomyl dengan cara 
$\begin{array}{lcr}\text { disemprotkan } & \text { ke } & \text { tanah, } \\ \text { menunjukkan } & \text { penurunan } & \text { yang }\end{array}$ berarti.

Berdasarkan hasil di atas, diduga dengan konsentrasi fungisida nabati dengan konsentrasi 100 ppm, 75 ppm dan 50 ppm dapat menghambat perkembangan koloni jamur tanah ditandai dengan besar kecilnya nilai Hambatan Relatif (HR). Dari hasil di atas pula, terlihat bahwa fungisida nabati dengan perlakuan 100 ppm paling efektif persentase penghambatannya, karena dapat menghambat pertumbuhan koloni jamur F. oxysporum. Penghambatan terhadap jamur $F$. oxysporum dari ketiga macam fungisida nabati secara in vitro di atas dapat terjadi karena diduga masing-masing fungisida nabati mempunyai kemampuan dan kepekaan yang berbeda-beda satu dengan yang lainnya. Fungisida nabati dengan perlakuan 100 ppm yang paling efektif persentase penghambatannya, karena pertumbuhan koloni jamur F.oxysporum menjadi terhambat.

\section{KESIMPULAN}

Diperoleh nilai toksisitas fungisida nabati tertinggi pada ekstrak daun sirsak dengan nilai HR $(69,44 \%)$ kategori berpengaruh, ditandai dengan diameter koloni $F$. oxysporum $(2,75 \mathrm{~cm})$ dan yang terendah toksisitasnya terdapat pada ekstrak daun jeruk purut dengan nilai HR (49,81\%) kategori cukup berpengaruh, ditandai dengan diameter koloni jamur $F$. oxysporum $(4,52 \mathrm{~cm})$. Semakin tinggi konsentrasi yang diujikan maka semakin tinggi toksisitas dari fungisida nabati yang diberikan.
DAFTAR PUSTAKA

Agrios GN (2005) Plant Pathology $4^{\text {th }}$ Ed. Academic Press, San Diego California (US).

Apriani L, Suprapta DN, Temaja IGRM (2014) Uji Efektivitas Fungisida Alami dan Sintetis dalam Mengendalikan Penyakit Layu Fusarium pada Tanaman Tomat yang Disebabkan oleh Fusarium oxysporum f.sp. lycopersici. E-Jurnal Agroekoteknologi Tropika 3 (3): 137 - 147.

Apriyuslim RP (2015) Uji Aktivitas Antibakteri Ekstrak Etanol Daun Sirsak (Annona muricata L.) Terhadap Salmonella typhi Secara In Vitro. [Skripsi]. Pendidikan Dokter, Universitas Tanjungpura, Pontianak.

Badan Pusat Statistik (2017) Statistik Tanaman Sayuran dan Buah-buahan Semusim Indonesia 2017 https://www.bps.go.id/publicatio n/2018/10/05/bbd90b867a6ee37 2e7f51c43/statistik-tanamansayuran-dan-buah---buahansemusim-indonesia-2017.html. Diakses pada 15 Juni 2019.

Damico DCS, Freire MGM, Gomes VM, Toyama MH, Marangoni S, Novello JC, Macedo MLR (2003) Isolation and characterization of a lectin from Annona muricata seeds. Journal of Protein Chemistry 22: 655661.

Gomez BS, Siquiera ABS, Maia RCC, Giampaoli V, Teixeiras $\mathrm{EH}$, Arrudas FVS, Nascimento KS, Lima AN, Motta CMS, Cavada BS, Porto ALF (2012) Antifungal Activity of Lectins Against Yeast of Vaginal Secretion. Brazilian Journal of Microbiology 770-778. 
Halimursyadah, Syamsuddin HA, Putri (2017) Efektivitas

Fungisida Nabati dalam Menghambat Aktivitas Seed Born Pathogen pada Benih Tomat secara in vitro. Prosiding Seminar Nasional Pascasarjana (SNP) Unsyiah (April 13, 2017), Banda Aceh, Indonesia.

Hujjatusnaini N (2012) Uji Potensi

Ekstrak Daun Ketepeng Cina (Cassia alata L.) Terhadap Penghambatan Pertumbuhan Trichophyton sp. El-Qudwah.

Humaidi F (1999) Penelitian Khasiat Analgetika Minyak Atsiri Dan Ekstrak Etanol Rimpang Curcuma Zedoaria Rosc. Dengan Metode" Writhing Test" Pada Mencit . [Skripsi]. Fakultas Farmasi Universitas Airlangga, Surabaya.

Kartasapoetra G (1996) Budidaya Tanaman Berkhasiat Obat. Rineka Cipta. Jakarta.

Leboeuf M, Cave A, Bhaumik PK, Mukherjee $\mathrm{B}$, Mukherjee $\mathrm{R}$ (1982) The Pytochemistry of The Annonaceae. Phytochemistry 21(12): 27832813.

Linda $\mathrm{R}$, S Khotimah, dan Elfiyanti (2011) Aktivitas Ekstrak Daun Ketepeng Cina (Cassia cilata Linn.) Terhadap pertumbuhan jamur Cercospora personatum. Jurnal Biopropal Industri 2(1):17.

Nakahara K, Alzoreky NS, Yoshihashi T, Nguyen HTT, dan G Trakoontivakorn (2003) Chemical composition and antifungal activity of essential oil from Cymbopogon nardus (citronella grass). JARQ. 37(4): 249-252.

Noveriza $\mathrm{R}$ dan Miftakhurohmah (2010) Efektivitas Ekstrak Metanol Daun Salam (Eugenia polyantha) Dan Daun Jeruk Purut (Cytrus hystrix) Sebagai Antijamur

Pada
Pertumbuhan Fusarium oxysporum. Jurnal Littri 16(1):611.

Oka IN (1995) Pengendalian Hama Terpadu dan Implementasinya Di Indonesia. Gadjah Mada University Press, Yogyakarta.

Pelczar MJ dan Chan ECS (2005) Dasar-dasar Mikrobiologi 1, Alih bahasa: Hadioetomo, R. S., Imas, T., Tjitrosomo, S.S. dan Angka, S. L. UI Press: Jakarta.

Phabiola TA (2004) Penggunaan Ekstrak Beberapa jenis Tumbuhan untuk Mengendalikan Penyakit Layu Pisang pada Pembibitan dari Bonggol. [Thesis]. Program Studi Bioteknologi Pertanian, Universitas Udayana, Denpasar.

Prajnanta (1995) Agribisnis Cabai Hibrida. Penebar Swadaya, Jakarta.

Purwantisari S, Ferniah RS, dan Raharjo B (2008) Pengendalian Hayati Penyakit Lodoh (Busuk Umbi Kentang) Dengan Agens Hayati Jamur-Jamur Antagonis Isolat Lokal. Bioma 10(2): 13-19.

Salisburry FB dan Ross CW (1998) Fisiologi Tumbuhan. Jilid 2. ITB. Bandung.

Semangun H (2006) Penyakitpenyakit Tanaman Hortikultura di Indonesia. Gadjah Mada University Press, Yogyakarta.

Shim YK, Mlynarek SP, Wijngaarden E (2009) Parental Exposure to Pesticides and Childhood Brain Cancer: U.S. Atlantic Coast Childhood Brain Cancer Study. Environmental Health Perspectives 117(6). https://www.ncbi.nlm.nih.gov/pm c/articles/PMC2702394/. [30 Oktober 2018].

Suresh K, Deepa P, Harisaranraj R, Vaira, Achudhan V (2008) Antimicrobial and Phytochemical Investigation of the leaves of Carica Papaya L., Cynodondactylon (L.) Pers., Euphorbia hirta L., Melia 
azedarach L. and Psidium guajava L. Ethnobotanical Leaflets 12: 1184-1191.

Tirtana ZYG, Sulistyowati L, Cholil A (2013) Eksplorasi Jamur Endofit Pada Tanaman Kentang (Solanum tuberosum L.) Serta Potensi Antagonismenya Terhadap Phytophthora infestans (Mont.) de Barry Penyebab Penyakit Hawar Daun Secara In Vitro. Jurnal HPT. 1(3): 91-101.

Umboh S (2016) Analisis Kadar Residu Pestisida dan Bioakumulasinya Terhadap Laba-laba Predator, Fisikokimia dan Biologi Tanah di Pertanaman Sayuran Kubis. [Disertasi]. Pascasarjana Universitas Sam Ratulangi, Manado.
Wachjadi M, Soesanto L, Manan A, dan Mugiastuti E (2013) Pengujian Kemampuan Mikroba Antagonis untuk mengendalikan Penyakit Hawar Daun dan Layu Bakteri pada Tanaman Kentang Di Daerah Endemis. Arigin 17(2):92-102.

Wu FE, Gu ZM, Zeng L, Zhao GX, Zhang $\mathrm{Y}$, McLaughlin JL, and Sastrodihardjo S (1995) Two New Cytotoxic Monotetrahydrofuran

Annonaceous Acetogenins, Annomuricins $\mathrm{A}$ and $\mathrm{B}$, from the Leaves of Annona muricata L. Journal of Natural Products 58: 830-836.

Zusfahair, Ningsih DR, Nur F (2014) Karakterisasi Papain Dari Daun Pepaya (Carica Papaya L.). Molekul 9(1): 44-55. 